\title{
Fungi Associated with and Influence of Moisture on Development of Kernel Mold of Hazelnut
}

\author{
J. W. Pscheidt, ${ }^{1, \dagger}$ S. Heckert, ${ }^{1}$ M. Wiseman, ${ }^{1}$ and L. Jones ${ }^{2}$ \\ ${ }^{1}$ Department of Botany \& Plant Pathology, Oregon State University, Corvallis, OR 97331; and ${ }^{2}$ Plant \& Food Research (USA) \\ LLC, Davis, CA 95616
}

\begin{abstract}
Kernel mold on hazelnuts is defined by the United States Department of Agriculture, U.S.A., as any visible fungal growth either on the outside or inside of the kernel. Only one yeast and one filamentous fungus have been associated with kernel mold of hazelnut in Oregon. In this report, fungi were isolated from kernels with mold and identified using morphological and molecular characters. Penicillium spp. were isolated most often from kernels with mold, but species of Aspergillus and Cladosporium and Diaporthe rudis were also frequently isolated. Additional fungi from three other genera were also isolated. All of the same fungi were also isolated from symptomless kernels. Eremothecium coryli or Ramularia sp.

previously associated with kernel defects in Oregon were not found associated with symptoms of kernel mold. Incidence of mold was the highest when nuts were incubated in moist chambers on wet, nonautoclaved orchard soil and was significantly higher than kernel mold found in nuts incubated on either air-dried soil or wet, autoclaved soil. Preventing hazelnuts from coming in contact with wet soil in the field using elevated wire screens resulted in significantly less mold development in two out of three years evaluated. Nuts on screens had a greater chance to dry out between rainstorms as measured by significantly lower nut moisture levels at harvest.
\end{abstract}

Hazelnuts (Corylus avellana L.) are grown in the Pacific Northwest on trees trained to a single trunk, allowed to fall to the ground naturally, swept into windrows, and immediately collected into large tote boxes. Tote boxes are delivered to processors where a whole nut sample (shells with kernels, fresh or dried) is cracked open and evaluated for defects such as mold. "Mold" is defined as any visible growth of fungi either on the outside or inside of the hazelnut kernel (Anonymous 2008). In practice, it means any fuzzy mycelial growth on or in the kernel is classified as mold. In Oregon, moldy kernel incidence averages 0.5 to $1 \%$ annually; but mold incidence in some individual hazelnut orchards can be much higher at 3 to $10 \%$ (Doster et al. 2002). Hazelnut growers in Oregon are paid on a total harvested weight basis minus the percentage of defects, which includes mold as well as rancid or decayed nuts, insect injury, shrivels, and blanks. Processors can sell in-shell hazelnuts as U.S. No. 1 only if mold, rancid, decay, and insect defects are together below 5\% (Anonymous 2008).

Oregon grows many cultivars, such as Barcelona and Ennis, that do not have a high frequency of mold. Recent cultivar releases with high resistance to eastern filbert blight (EFB), including Lewis and Santiam, have had higher levels of mold than Barcelona (Mehlenbacher et al. 2007). The hazelnut cultivar Jefferson has resistance to EFB but also consistently lower levels of mold than Lewis or Santiam (McCluskey et al. 2011). Cultivars grown in Turkey were reported to have low mold levels (Beyhan 2000) despite Turkish cultivars being more susceptible to mold under Oregon conditions (Mehlenbacher et al. 1993). Susceptibility of hazelnut kernels to mold is highly heritable and can be minimized when selecting new cultivars (Mehlenbacher et al. 1993).

Mold is sporadically a problem in all hazelnut growing regions worldwide. In Oregon, high levels of mold are associated with rains

${ }^{\dagger}$ Corresponding author: J. W. Pscheidt; pscheidj@science.oregonstate.edu

Funding: This research was supported in part by the Oregon Hazelnut Commission, which is a Commodity Commission and agency of the State of Oregon under the Oregon Department of Agriculture.

Accepted for publication 27 October 2018.

(C) 2019 The American Phytopathological Society during harvest (Pscheidt and Ocamb 2018). Protecting trees that are susceptible to kernel mold from spring rainfall using plastic tents resulted in significantly less mold (Pscheidt and Cluskey 2001; Pscheidt et al. 2000). In a high-elevation production area with presumably higher rainfall, higher mold levels were observed in Spain (Tous et al. 2001). Mold can also be a problem when nut-filled bins are left out in the rain before drying (Pscheidt and Cluskey 2007) or when nuts are collected into nylon sacks that hold in moisture (Ozay et al. 2008). Drying and/or roasting help increase storage life of hazelnuts, in part by limiting fungal growth (Kinderlerer and Phillips-Jones 1992; Özilgen and Özdemir 2001).

Research on specific causes of mold is scarce. Many different fungi are easily isolated after surface-sterilization from shells and/or kernels with or without any specific symptoms, before or after harvest. Fungi associated with specific symptoms would not be classified as mold but as decay or discoloration in the absence of active mycelial growth (Anonymous 2008). Koch's postulates have not been completed for any of the associated fungi (Sezer and Dolar 2016).

Numerous fungi can be found associated with kernels after they have been harvested, shelled, processed, and shipped. Aspergillus spp. are of particular interest due to the potential for mycotoxin production (Abdel-Hafez and Saber 1993; Kabak 2016; Kinderlerer and Phillips-Jones 1992; Özilgen and Özdemir 2001; Şimşek et al. 2002). In Turkey, Aspergillus, Penicillium, Rhizopus, Syncephalastrum, Cladosporium, Fusarium, and Geotrichum species were found on kernels, but it was not clear if any of these were a problem, even with Aspergillus because no aflatoxins were detected (Şimşek et al. 2002). After dilution plating, the following fungi were obtained from kernels imported into the UK from Turkey: Absidia corymbifera, Aspergillus spp., Chrysosporium xerophilum, Eurotum spp., Mucor circinelloides, Paeciloymyces variotii, Penicillium spp., Trichoderma spp., and Wallemia sebi (Kinderlerer and Phillips-Jones 1992). Similar fungi of overall 14 genera and 34 species were found on hazelnuts from various markets in Egypt with seven species representing three genera (Aspergillus, Emericella, and Rhizomucor) recovered when isolation plates were incubated at $45^{\circ} \mathrm{C}$ (Abdel-Hafez and Saber 1993). The following fungal genera were obtained, after dilution plating, from dried hazelnut kernels grown in Nebraska: Penicillium (most predominant), Alternaria, Chrysonilia, and Cladosporium spp. (Xu et al. 2011). Kernel defects were not evaluated in each of these cases. In another study from Turkey, nine fungal genera 
were isolated with Cladosporium spp., Penicillium spp., and Trichothecium roseum most frequently associated with kernel defects (Sezer and Dolar 2016). Although each genus was able to colonize disinfected kernels, none produced symptoms of specific kernel defects.

The yeast Eremothecium coryli (Peglion) Kurtzman 1995 (formerly Nematospora coryli) was consistently associated with a disease known as kernel spot in Oregon (Halliwell and Miller 1962). Kernel spot is characterized by dark, sunken lesions of varied size and shape on the kernel surface. All surfaces of the kernel can be affected. The disease has only been identified three times by the Oregon State University (OSU) Plant Clinic since 1954 and is not considered a major problem in Oregon. Kernel spot, however, is a problem on hazelnut in Bulgaria (Bobev et al. 2017). The yeast is also involved in stigmatomycosis of pistachio in California (Michailides and Morgan 1990).

The most common symptom on hazelnuts associated with fungi in Oregon is a necrosis of the kernel tip where it attaches to the funiculus (Pscheidt and Ocamb 2018). Necrosis usually extends into the kernel for a few millimeters. Kernel tips are blackened and shriveled, partly reducing kernel quality. These symptoms are locally referred to as "Tip Mold" but would not be counted as mold when evaluating kernel quality. The Ramularia (asexual) stage of Mycosphaerella punctiformis (Pers.:Fr.) Starbäck was consistently isolated from kernels with these symptoms (Ebrahem et al. 1996). Black tips on kernels in other parts of the world have been associated with weak sutures in the shell (Özilgen and Özdemir 2001).

Despite the increased use of fungicides for the management of EFB in Oregon for the last 20 years, mold levels do not seem to have changed. The use of fungicides (FRAC codes M1, M5, 3, and 11) from flowering through early shoot elongation did not affect mold development (Pscheidt and Cluskey 2002, 2003).

Studies on kernel mold of hazelnut were initiated to better understand what fungi might be involved in Oregon and what role moisture might have for mold development at harvest.

\section{Materials and Methods}

Identification of fungi. Whole nuts (shells and kernels) were collected from a block of four hazelnut breeding selections (379.050, $380.057,385.013$, and 391.001) planted in 1994 at a $3 \times 6.1 \mathrm{~m} \mathrm{spac}-$ ing at the Botany and Plant Pathology Field Laboratory (BPPFL), OSU, Corvallis, OR. These breeding selections were planted for studying their consistent high incidence of moldy kernels. Nuts of cultivars Ennis were collected from a 0.4 ha experimental orchard at the BPPFL planted in 1986 at a $6.1 \times 6.1 \mathrm{~m}$ spacing. Additional nuts of the cultivar Lewis were also collected from a commercial orchard located near Amity and Canby, OR.

Following Pacific Northwest (PNW) commercial practices, nuts were allowed to naturally fall onto the orchard soil throughout late summer and fall of 2013, 2014, and 2015. Thousands of nuts were randomly collected from the ground under the cultivars identified above and processed for isolation without drying. Unsterilized whole nuts were cracked open with a hammer and evaluated for mold based on USDA inspection standards (Anonymous 2008). To reduce heavy contamination, 2,190 moldy kernels, including seed coats, were then surfaced sterilized in $0.525 \%$ final concentration bleach (made from $5.25 \% \mathrm{NaOCl}$ ) for $3 \mathrm{~min}$, rinsed for $1 \mathrm{~min}$ in sterile deionized water, and allowed to air-dry (in a laminar flow hood) for $5 \mathrm{~min}$. Kernels were then placed directly (two kernels per plate) onto petri plates containing half-strength potato dextrose agar (PDA). Plates were incubated at 18 to $20^{\circ} \mathrm{C}$ for 5 to 7 days under natural daylight alternations and were then examined visually for fungal growth. Fungal mycelia were transferred onto new PDA plates for isolation, incubated similarly, and checked after another 5 to 7 days. A total of 1,632 asymptomatic (nonmoldy) kernels were processed and plated following the same procedures in 2014 and 2015.

In 2017, direct mycelial isolations were used to verify the type of fungi found on moldy kernels. Prior to cracking, hundreds of nuts were surfaced sterilized with $0.525 \%$ bleach (made from $5.25 \%$ $\mathrm{NaOCl}$ ) for 5 to $10 \mathrm{~s}$, rinsed for $1 \mathrm{~min}$ in sterile deionized water, and allowed to air-dry (in a laminar flow hood) for $5 \mathrm{~min}$. Using a simple hand held nut cracker (SALT Nutcracker), each nut was carefully cracked and examined for mold. The nut cracker was placed in 5\% ethanol between each nut cracking. Hyphae from 219 kernels with mold were carefully transferred onto petri plates containing half-strength potato dextrose agar (PDA) plus streptomycin. Plates were incubated at 18 to $20^{\circ} \mathrm{C}$ for 5 to 7 days under natural daylight alternations and were then examined visually for fungal growth. Fungal hyphal tips were transferred onto new PDA plates for isolation, incubated similarly, and checked after another 5 to 7 days.

Organisms obtained were grouped based on cultural characteristics and microscopic morphology, coded sequentially starting with JWP-1, and initially identified to genus. Fungal cultures were then hyphal-tipped transferred to quarter-strength PDA amended with $100 \mathrm{mg} /$ liter streptomycin sulfate and incubated for 3 to 7 days. Mycelia and spores were scraped from plates, and genomic DNA was extracted using the FASTSpin extraction kit according to the manufacturer's directions (MP Biomedicals, Santa Ana, CA). Initial fungal molecular identification of isolates was completed by sequencing the ITS (internal transcribed spacer) region, using the primer pair ITS1/ ITS4 (White et al. 1990).

Fungal identification was additionally done by sequencing part of the translation elongation factor $1-\alpha$ (TEF1 $\alpha$ ) using the EF526F/ EF1567R primer pair (Rehner and Buckley 2005). Amplification using the EF526F/EF1567R primer pair was unsuccessful for isolate JWP-6; therefore, part of the $\beta$-tubulin-2 gene (TUB2) was also sequenced using the $\mathrm{Bt} 2 \mathrm{a} / \mathrm{Bt} 2 \mathrm{~b}$ primer pair (Glass and Donaldson 1995). The $\beta$-tubulin-2 gene (TUB2) was also used to identify isolate JWP-9.

The PCR reaction mixtures consisted of $0.2 \mu \mathrm{M}$ of each primer, $1 \times$ AccuStart II PCR ToughMix (Quantabio, Beverly, MA, USA), 1× gel loading dye, and 0.5 to $50 \mathrm{ng}$ of template DNA in a final volume of $25 \mu \mathrm{l}$. Amplifications were conducted in a C1000 Touch Thermal Cycler (Bio-Rad, Hercules, CA). For ITS and TEF1 $\alpha$ products, amplification started with an initial denaturation cycle of $3 \mathrm{~min}$ at $95^{\circ} \mathrm{C}$, followed by 35 cycles of $30 \mathrm{~s}$ at $95^{\circ} \mathrm{C}, 45 \mathrm{~s}$ at $57^{\circ} \mathrm{C}$, and $60 \mathrm{~s}$ at $72^{\circ} \mathrm{C}$ with a final extension cycle of $5 \mathrm{~min}$ at $72^{\circ} \mathrm{C}$. For TUB2 products, amplification started with an initial denaturation cycle of $3 \mathrm{~min}$ at $95^{\circ} \mathrm{C}$, followed by 35 cycles of $30 \mathrm{~s}$ at $95^{\circ} \mathrm{C}, 30 \mathrm{~s}$ at $52^{\circ} \mathrm{C}$, and $30 \mathrm{~s}$ at $72^{\circ} \mathrm{C}$ with a final extension cycle of $5 \mathrm{~min}$ at $72^{\circ} \mathrm{C}$. Successful amplification was verified on a $1.5 \%$ agarose gel poststained with ethidium bromide. PCR amplicons were then treated with ExoSAP-IT as directed by the manufacturer (Affymetrix Inc., Santa Clara, CA) and sequenced with forward and reverse primers using a ABI 3730 capillary sequencer at the Center for Genome Research and Biocomputing (OSU, Corvallis, OR). Contigs were handedited and assembled de novo using Geneious 9 (Biomatters Ltd., Auckland, NZ). Sequences were compared with accessions in the GenBank database using the Basic Local Alignment Search Tool (BLAST). In addition, Fusarium spp. were also compared with the curated accessions in the Fusarium-ID database (Geiser et al. 2004).

Effect of moisture. The effect of high humidity and soil moisture on mold development was evaluated by incubating nuts in moisture chambers. Hazelnuts from a commercial Lewis orchard were raked and hand harvested from the ground on 15 Sep 16 and 3 Oct 17 , placed into gunnysacks, and stored at 4.4 and $15.5^{\circ} \mathrm{C}$, respectively, until use within the next few weeks. Nuts were surface sterilized with $0.525 \%$ bleach (made from $5.25 \% \mathrm{NaOCl}$ ) for $1 \mathrm{~min}$ and allowed to air dry at ambient room temperature $\left(18.3\right.$ to $\left.21.1^{\circ} \mathrm{C}\right)$ on paper towels. Nuts were then placed into plastic moist chambers $(25 \times 31 \times$ $10 \mathrm{~cm}$ ) onto either a wire mesh screen $7.6 \mathrm{~cm}$ above the bottom or onto a 2-cm layer of orchard soil. Although nuts were in a single layer on screens or soil, many were touching each other. Nuts were incubated for 14 days on wire screens within moist chambers either dry (with lids off and open to low ambient humidity) or humid (lids on with wet paper towels on the bottom of the chamber) where nuts were not in contact with the wet towels. Nuts were also incubated on orchard soil within moist chambers either dry (with lids off and open to the laboratory environment) or wet (lids on with water saturated soil). In these later cases, nuts were always in contact with either air-dried or wet soil. 
The orchard soil (Camas gravelly sandy loam) was collected from the block of hazelnut breeding selections described above and dried by allowing it to sit open in a greenhouse exposed to ambient temperature $\left(15.5^{\circ} \mathrm{C}\right)$ and low humidity. This air-dried soil was placed into moist chambers and saturated by adding water until visibly wet.
Moist chambers were then carefully tipped onto their sides to allow excess water to drain.

Sets of 200 nuts per moist chamber were replicated 8 times for each of 4 treatments (wire screens dry or wet, orchard soil dry or wet) for a total of 1,600 nuts per treatment. The experiment was

Table 1. Molecular identification of mold-associated fungi isolated from hazelnuts where assemblies were compared with accessions in the GenBank database using the BLASTn algorithm

\begin{tabular}{|c|c|c|c|c|}
\hline \multirow[b]{2}{*}{ Codew $^{w}$} & \multicolumn{3}{|c|}{ Accession numbers of top matches ${ }^{x}$} & \multirow[b]{2}{*}{ Identification } \\
\hline & ITS $^{y}$ & TEF1a $^{y}$ & $\mathbf{B t} 2 \mathbf{b}^{\mathbf{y}}$ & \\
\hline JWP - 1 & KT692597 584/584 (100\%) & $\begin{array}{l}\text { GU320796 } \\
469 / 470(99 \%)\end{array}$ & - & Gnomoniopsis idaeicola \\
\hline JWP - 3 & $\begin{array}{l}\text { NR_144906 } 547 / 547(100 \%) \\
\text { KX464093 }{ }^{\mathrm{T}} \\
506 / 506(100 \%)\end{array}$ & XM_020275852 $504 / 511(99 \%)$ & - & Diplodia sp. \\
\hline JWP - 4 & KX953371 471/471 (100\%) & $\begin{array}{l}\text { LT746198 } \\
431 / 439(98 \%) \\
\text { KT350607 } \\
430 / 439(98 \%)\end{array}$ & - & Fusarium lateritium \\
\hline JWP - 5 & $\begin{array}{l}\text { FD_01845_rDNA-ITNL-1153z } \\
435 / 435(100 \%)\end{array}$ & $\begin{array}{l}\text { Fusarium culmorum } \\
\text { 395/397 }(99 \%) \\
\text { TMTL }\end{array}$ & - & Fusarium culmorum \\
\hline JWP - 6 & $\begin{array}{l}\mathrm{JF} 450756^{\mathrm{T}} \\
462 / 462(100 \%) \\
\text { NR_103604 } \\
492 / 492(100 \%)\end{array}$ & Did not amplify & $\begin{array}{l}\text { HE984408 }{ }^{\mathrm{T}} \\
521 / 521(100 \%) \\
\text { EF661086 } \\
508 / 508(100 \%)\end{array}$ & $\begin{array}{l}\text { Aspergillus tubingensis, A. pulverulentus, or } \\
\text { A. costaricaensis }\end{array}$ \\
\hline JWP - 7 & $\begin{array}{l}\text { KT600440 514/514 (100\%) } \\
\text { NR_119662 T } \\
\text { 499/499 (100\%) }\end{array}$ & $\begin{array}{l}\mathrm{EF} 679479^{\mathrm{T}} \\
425 / 426(99 \%) \\
\mathrm{EF} 679478 \\
425 / 426(99 \%)\end{array}$ & & Cladosporium tenellum or C. rhusicola \\
\hline JWP - 8 & $\begin{array}{l}\text { NR_111846 } \\
554 / 555(99 \%) \\
\text { NR_137106 } \\
552 / 555(99 \%) \\
\text { KC843331 } \\
551 / 555(99 \%)\end{array}$ & $\begin{array}{l}\text { KC343963 } \\
532 / 532(100 \%)\end{array}$ & - & Diaporthe rudis \\
\hline JWP - 9 & $\begin{array}{l}\mathrm{KC} 411744^{\mathrm{T}} \\
465 / 465(100 \%) \\
\text { NR_077153 } \\
\text { 484/484 (100\%) } \\
\text { GU256746 } \\
\text { 470/470 (100\%) }\end{array}$ & $\begin{array}{l}\text { KP009000 } \\
654 / 654(100 \%) \\
\text { FJ930987 } \\
566 / 566(100 \%)\end{array}$ & $\begin{array}{l}\text { LC052725T } \\
214 / 217(99 \%)\end{array}$ & $\begin{array}{l}\text { Penicillium pseudocasei, } P \text {. crustosum, or } \\
\text { P. chrysogenum }\end{array}$ \\
\hline
\end{tabular}

Table 2. Proportion of fungi isolated from hazelnut kernels with mold (visible mycelium after cracking open shells) collected from 2013 to 2015

\begin{tabular}{|c|c|c|c|c|c|c|c|}
\hline \multirow[b]{2}{*}{ Code } & \multirow[b]{2}{*}{ Identification ${ }^{y}$} & \multicolumn{5}{|c|}{ Cultivar ${ }^{\mathrm{z}}$} & \multirow[b]{2}{*}{ Total $(\%)$} \\
\hline & & $379.050(\%)$ & $385.013(\%)$ & $391.001(\%)$ & Ennis (\%) & Lewis $(\%)$ & \\
\hline- & No organisms isolated & 0 & 0 & 0 & 0 & 0 & 0 \\
\hline JWP - 1 & Gnomoniopsis idaeicola & 11 & 8 & 9 & 17 & 30 & 10 \\
\hline JWP - 2 & Unidentified bacteria & 13 & 7 & 10 & 17 & 7 & 10 \\
\hline JWP - 3 & Diplodia sp. & 8 & 5 & 9 & 13 & 7 & 7 \\
\hline JWP - 4 & Fusarium lateritium & 5 & 2 & 10 & 0 & 3 & 5 \\
\hline JWP - 5 & Fusarium culmorum & 5 & 2 & 9 & 8 & 1 & 5 \\
\hline JWP - 6 & Aspergillus sp. & 21 & 18 & 26 & 21 & 13 & 21 \\
\hline JWP - 7 & Cladosporium $\mathrm{sp}$. & 16 & 21 & 14 & 13 & 25 & 17 \\
\hline JWP - 8 & Diaporthe rudis & 32 & 11 & 40 & 13 & 15 & 28 \\
\hline JWP - 9 & Penicillium spp. & 54 & 50 & 54 & 21 & 28 & 52 \\
\hline JWP - 10 & Ramularia sp. (Tip Mold) & 0 & $<1$ & 0 & 0 & 0 & $<1$ \\
\hline \multicolumn{2}{|c|}{ Number of nuts examined } & 862 & 607 & 626 & 24 & 71 & 2,190 \\
\hline
\end{tabular}

y Unsterilized hazelnuts were cracked open and determined to have mold or not based on USDA inspection standards. Kernels with seed coats were then surfaced sterilized in $10 \%$ bleach for $3 \mathrm{~min}$, rinsed for $1 \mathrm{~min}$ in sterile deionized water, air dried for $5 \mathrm{~min}$, and placed onto $1 / 2$ strength PDA. Plates were incubated at 18 to $20^{\circ} \mathrm{C}$ for 5 to 7 days, examined for fungal growth, which was then transferred onto a new PDA plate for isolation. Fungi obtained were identified using morphological and molecular characteristics.

${ }^{\mathrm{z}}$ Hazelnut cultivars examined include the commercial cultivars Ennis and Lewis as well as the numbered selections 379.050, 385.013, and 391.001 from the OSU hazelnut breeding program. 
repeated twice each year starting on 12 Oct 2016, 2 Nov 2016, 25 Oct 2017, and 1 Nov 2017. After 2 weeks incubation at ambient room temperature, nuts were cracked open with a hammer and evaluated for kernel mold (any kernel with visible mycelial growth).

Treatments were analyzed as a complete block ANOVA and treatment means were compared using Fisher's protected LSD $(P=0.05)$ procedure (Agricultural Research Manager software, Gylling Data Management, Inc., Brookings, SD).

Effect of sterile soil. The effect of sterilized soil on mold development was also evaluated by incubating nuts in moisture chambers. Nuts were collected and processed as described above. The same orchard soil was autoclaved and allowed to cool and dry for $16 \mathrm{~h}$. Sets of 200 nuts per moist chamber were replicated 8 times for each of 4 treatments (orchard soil dry or wet, sterilized soil dry or wet) for a total of 1,600 nuts per treatment. The experiment was repeated twice each year starting on 17 Oct 2016, 7 Nov 2016, 27 Oct 2017, and 3 Nov 2017. Nuts were incubated and evaluated as described above. Treatments were analyzed as a complete factorial ANOVA with two factors with soil (autoclaved or not) as one factor and wetness (dry or wet) as another factor. Treatment means were compared using Fisher's protected LSD $(P=0.05)$ procedure (Agricultural Research Manager software, Gylling Data Management, Inc., Brookings, SD).

Nut harvest location. Mold incidence on nuts allowed to fall onto the ground, onto plastic weed cloth, or onto wire screens was determined in a block of hazelnut breeding selections from 2012 to 2014 and in a commercial Lewis orchard near Canby, OR in 2014. The three treatments (ground, weed cloth, and wire screens) in each orchard were arranged in a randomized complete block design. Each treatment was placed under four single trees in each of two hazelnut selections 379.050 and 380.057 in 2012, under selections 379.050 and 385.013 in 2013 and 2014, and under Lewis trees in 2014.

The orchard floor under trees was cleared and prepared for nut drop by blowing old nuts and debris with a leaf blower into the grass strip between trees, mowing weeds, and using herbicides to prevent new weed emergence during the summer. In early Sep 2012, four $0.91 \mathrm{~m}$ sections of weed cloth (black, polypropylene nonwoven landscape fabric from Westward), for a total area of $5.57 \mathrm{~m}^{2}$ were placed under each tree and held to the ground with wooden posts. In early Sep 2013 and 2014, only two sections of $0.91 \mathrm{~m}$ weed cloth, for a total area of $4.46 \mathrm{~m}^{2}$, were placed under each tree and held to the ground with wooden posts. In addition, each year two $2.55 \times$ $0.97 \mathrm{~m}$ wooden frames covered with wire screens, for a total area of $4.9 \mathrm{~m}^{2}$, were placed under different trees and elevated $15.2 \mathrm{~cm}$ off the ground using cinder blocks.

Nuts were allowed to fall naturally onto bare soil, weed cloth sections, or wire screens. Nuts that fell onto weed cloth or wire screens did not come in contact with the soil but were exposed to rainfall similar to those that fell to the ground. A total of 70 to 100 nuts were collected from under each tree on 29 to 30 Oct 2012. A total of 400 nuts were collected from under each tree on 21 to 22 Oct 2013 and from under each 385.013 tree on 28 Oct 2014 and from under each 379.050 tree on 4 Nov 2014. A total of 200 nuts were collected from under each Lewis tree on 6 Oct 2014. Nuts were then cracked open and evaluated for kernel mold.

Nut moisture content was calculated in 2013 and 2014 based on the difference in weight of 25 nuts (about 50 to $75 \mathrm{~g}$ ) at harvest and weight after drying at 70 to $80^{\circ} \mathrm{C}$ for 48 to $72 \mathrm{~h}$.

Treatments were analyzed as a randomized complete block ANOVA and treatment means were compared using Fisher's protected LSD $(P=0.05)$ procedure (Agricultural Research Manager software, Gylling Data Management, Inc., Brookings, SD).

\section{Results}

Identification of mold fungi. One or more fungi were consistently isolated from hazelnut kernels with visible mold (Table 1). All kernels with visible mold had any of nine different fungi isolated

Table 4. Effect of moisture on incidence of kernel mold when nuts are incubated in moist chambers

\begin{tabular}{|c|c|c|c|c|}
\hline \multirow[b]{3}{*}{ Treatment $^{\mathrm{x}}$} & \multicolumn{4}{|c|}{ Mold (\% kernels) $)^{\mathrm{y}}$} \\
\hline & \multicolumn{2}{|c|}{2016} & \multicolumn{2}{|c|}{2017} \\
\hline & 12 Oct & 2 Nov & 25 Oct & 1 Nov \\
\hline Wire Screens - Dry & $7.1 \mathrm{c}$ & $6.2 \mathrm{c}$ & $6.9 \mathrm{c}$ & $3.3 \mathrm{c}$ \\
\hline Wire Screens - Humid & $10.7 \mathrm{~b}$ & $20.8 \mathrm{~b}$ & $10.4 \mathrm{~b}$ & $13.0 \mathrm{~b}$ \\
\hline Orchard Soil ${ }^{\mathrm{z}}$ - Dry & $6.9 \mathrm{c}$ & $7.8 \mathrm{c}$ & $5.7 \mathrm{c}$ & $3.2 \mathrm{c}$ \\
\hline Orchard Soil ${ }^{\mathrm{z}}$ - Wet & $31.1 \mathrm{a}$ & $46.3 \mathrm{a}$ & $17.0 \mathrm{a}$ & $18.9 \mathrm{a}$ \\
\hline
\end{tabular}

${ }^{x}$ Wire Screens - Dry $=$ nuts were incubated on wire screens with moist chamber lids off and open to ambient humidity; Wire Screens - Humid = nuts were incubated on wire screens with moist chamber lids on and wet paper towels on the bottom of the chamber; Orchard Soil - Dry = nuts were incubated in contact with air-dried soil with moist chamber lids off and open to ambient humidity; Orchard Soil - Wet = nuts were incubated in contact with water saturated soil.

${ }^{y}$ In each experiment, sets of 200 nuts per moist chamber were replicated 8 times for each of 4 treatments (wire screens dry or wet, orchard soil dry or wet) for a total of 1,600 nuts per treatment. After 2 weeks incubation at ambient room temperature, nuts were cracked open with a hammer and evaluated for kernel mold (any kernel with visible mycelial growth). Means followed by the same letter do not differ significantly based on Fisher's protected LSD $(P=0.05)$

${ }^{z}$ Orchard soil (Camas gravelly sandy loam) was collected from a hazelnut orchard, dried, and placed into moist chambers. Soil was saturated by adding water until visibly wet and then chambers were carefully tipped onto their sides to allow excess water to drain.

Table 3. Proportion of fungi isolated from hazelnut kernels without mold (no symptoms) collected from 2014 and 2015

\begin{tabular}{|c|c|c|c|c|c|c|c|}
\hline \multirow[b]{2}{*}{ Code } & \multirow[b]{2}{*}{ Identification ${ }^{y}$} & \multicolumn{5}{|c|}{ Cultivar $^{\mathbf{z}}$} & \multirow[b]{2}{*}{ Total $(\%)$} \\
\hline & & $379.050(\%)$ & $385.013(\%)$ & $391.001(\%)$ & Ennis (\%) & Lewis $(\%)$ & \\
\hline - & No organisms isolated & 7 & 4 & 14 & 56 & 43 & 20 \\
\hline JWP - 1 & Gnomoniopsis idaeicola & 7 & 14 & 16 & 14 & 21 & 13 \\
\hline JWP - 2 & Unidentified bacteria & 7 & 16 & 14 & 22 & 29 & 15 \\
\hline JWP - 3 & Diplodia sp. & 11 & 6 & 13 & 8 & 8 & 11 \\
\hline JWP - 4 & Fusarium lateritium & 7 & 6 & 9 & 0 & $<1$ & 6 \\
\hline JWP - 5 & Fusarium culmorum & 4 & 0 & 10 & 2 & 3 & 6 \\
\hline JWP - 6 & Aspergillus sp. & 37 & 49 & 36 & 10 & 20 & 32 \\
\hline JWP - 7 & Cladosporium sp. & 13 & 26 & 14 & 16 & 11 & 14 \\
\hline JWP - 8 & Diaporthe rudis & 28 & 10 & 30 & 17 & 16 & 25 \\
\hline JWP - 9 & Penicillium spp. & 66 & 59 & 56 & 16 & 22 & 50 \\
\hline JWP - 10 & Ramularia sp. (Tip Mold) & 7 & 0 & 2 & 3 & 8 & 4 \\
\hline \multicolumn{2}{|c|}{ Number of nuts examined } & 511 & 51 & 678 & 167 & 225 & 1,632 \\
\hline
\end{tabular}

y Unsterilized hazelnuts were cracked open and determined to have mold or not based on USDA inspection standards (2008). Kernels with seed coats were then surfaced sterilized in $10 \%$ bleach for $3 \mathrm{~min}$, rinsed for $1 \mathrm{~min}$ in sterile deionized water, air dried for $5 \mathrm{~min}$, and placed onto 1/2 strength PDA. Plates were incubated at 18 to $20^{\circ} \mathrm{C}$ for 5 to 7 days, examined for fungal growth which was then transferred onto a new PDA plate for isolation. Fungi obtained were identified using morphological and molecular characteristics.

${ }^{\mathrm{z}}$ Hazelnut cultivars examined include the commercial cultivars Ennis and Lewis as well as the numbered selections 379.050, 385.013, and 391.001 from the OSU hazelnut breeding program. 
including Aspergillus sp. (100\% nucleotide matches with Aspergillus tubingensis, A. pulverulentus, or A. costaricaensis), Cladosporium sp. (99 to $100 \%$ nucleotide matches with both C. tenellum or C. rhusicola), Diaporthe rudis (99 to 100\% nucleotide match), a Diplodia sp. (100\% nucleotide match with ex-type isolates of $D$. mutila and $D$. pyri), two Fusarium spp. (98 to $99 \%$ nucleotide matches with $F$. culmorum and F. lateritium), Gnomoniopsis idaeicola (99 to $100 \%$ nucleotide match), and many Penicillium spp. (100\% nucleotide matches with $P$. pseudocasei, $P$. crustosum, or $P$. chrysogenum). A Ramularia sp. was also found but was not common as it was found in only one kernel with visible mold (Table 2). Occasionally bacteria were associated with moldy kernels $(10 \%)$ but were not identified further (JWP-2, Table 2). Although not enumerated, many kernels with visible mold had more than one fungal species isolated from individual kernels.

Several different Penicillium spp. were isolated from kernels with visible mold, but only one isolate was included for molecular identification, which had top matches with $P$. pseudocasei, $P$. crustosum, or $P$. chrysogenum (Table 1). Penicillium spp. were the most predominate fungi isolated from all cultivars except Lewis and overall, being found in half the kernels with visible mold (Table 2).

Table 5. Effect of orchard and autoclaved soil on incidence of kernel mold when nuts are incubated in moist chambers

\begin{tabular}{|c|c|c|c|c|}
\hline \multirow[b]{3}{*}{ Treatment $^{\mathrm{x}}$} & \multicolumn{4}{|c|}{ Mold (\% kernels)y } \\
\hline & \multicolumn{2}{|c|}{2016} & \multicolumn{2}{|c|}{2017} \\
\hline & 17 Oct & $7 \mathrm{Nov}$ & 27 Oct & 3 Nov \\
\hline Orchard Soil ${ }^{\mathrm{z}}$ - Dry & $4.6 \mathrm{c}$ & $5.1 \mathrm{c}$ & $4.4 \mathrm{c}$ & $2.4 \mathrm{c}$ \\
\hline Orchard Soil - Wet & $41.4 \mathrm{a}$ & $48.5 \mathrm{a}$ & $19.1 \mathrm{a}$ & 16.2 \\
\hline Autoclaved Soil - Dry & $4.0 \mathrm{c}$ & 3.6 & & 3.2 \\
\hline Autoclaved Soil - Wet & $20.6 \mathrm{~b}$ & $38.1 \mathrm{~b}$ & $12.1 \mathrm{~b}$ & $13.3 \mathrm{~b}$ \\
\hline \multicolumn{5}{|c|}{$\begin{array}{l}\text { x Orchard or Autoclaved Soil - Dry = nuts were incubated in contact with air- } \\
\text { dried soil either nonautoclaved or autoclaved; Orchard or Autoclaved Soil - } \\
\text { Wet }=\text { nuts were incubated in contact with water saturated nonautoclaved or } \\
\text { autoclaved soil. }\end{array}$} \\
\hline \multicolumn{5}{|c|}{$\begin{array}{l}\mathrm{y} \text { In each experiment, sets of } 200 \text { nuts per moist chamber were replicated } 8 \\
\text { times for each of } 4 \text { treatments for a total of } 1,600 \text { nuts per treatment. After } \\
2 \text { weeks incubation at ambient room temperature, nuts were cracked open } \\
\text { with a hammer and evaluated for kernel mold (any kernel with visible my- } \\
\text { celial growth). Means followed by the same letter do not differ significantly } \\
\text { based on Fisher's protected LSD }(P=0.05) \text {. }\end{array}$} \\
\hline \multicolumn{5}{|c|}{$\begin{array}{l}{ }^{\mathrm{z}} \text { Orchard soil (Camas gravelly sandy loam) was collected from a hazelnut or- } \\
\text { chard, dried and placed into moist chambers. Additional soil was autoclaved } \\
\text { and allowed to cool and dry prior to placement in moist chambers. Soil was } \\
\text { saturated by adding water until visibly wet and then chambers were carefully } \\
\text { tipped onto their sides to allow excess water to drain. }\end{array}$} \\
\hline
\end{tabular}

Other fungi frequently isolated from kernels with visible mold included Aspergillus sp. (21\%), a Cladosporium sp. (17\%), and D. rudis $(28 \%)$ (Table 2). Depending on the cultivar, the frequency of occurrence was different. For example, D. rudis was the second most isolated fungus from the breeding cultivars $379.050(32 \%)$ or 391.001 (40\%), while Cladosporium sp. was the second most isolated fungus from Lewis (25\%).

The same fungi were isolated when mycelia were transferred from moldy nuts onto antibiotic amended media. All transferred mycelia developed mycelial colonies similar to JWP-1 or JWP-3 through JWP-9. Surface sterilizing nuts then carefully cracking each nut with a surface sterilized hand cracker to examine them individually for mold was laborious and time-consuming. Relative frequencies were not recorded since fewer nuts were examined.

Isolation from asymptomatic kernels found a similar set of organisms (Table 3). Many kernels (20\%) without visible mold did not yield any organisms; however, Penicillium spp. were again the most predominant fungi isolated, being found in half the kernels without visible mold. Aspergillus sp. (32\%) and D. rudis $(25 \%)$ were also frequently isolated from kernels without visible mold. The Ramularia sp. was not common but was found more frequently (4\%) and consistently in symptomless than in symptomatic kernels.

Effect of moisture and soil sterility. Lowest incidence of mold was associated in each experiment when nuts were incubated either dry on wire screens or on dry soil (Table 4). The highest incidence of mold occurred when nuts were incubated on wet soil and was significantly higher than mold found on nuts incubated on air-dried soil or either wire screen treatment. Nuts incubated at high humidity on wire screens without direct contact with moisture developed significantly more mold than when incubated dry.

A significant interaction between soil sterility and wetness factors meant each combination had to be analyzed separately rather than combining factors. Lowest mold was associated in all experiments when nuts were incubated on either soil treatment that was kept dry (Table 5). Highest incidence of mold occurred on wet, nonautoclaved orchard soil and was significantly higher than kernel mold found in nuts incubated on either air-dried soil or wet, autoclaved soil. Nuts incubated on wet, autoclaved soil had significantly less mold than nuts incubated on wet, nonautoclaved soil.

Nut harvest location. The percentage of kernels (from the breeding selections) with mold was significantly lower on nuts that were allowed to fall onto wire screens in the field rather than onto orchard soil in 2013 and 2014 but not in 2012 (Table 6). Nut moisture was also significantly lower for 379.050 nuts that fell onto wire screens rather than orchard soil in 2013 and 2014. Nut moisture was significantly lower for 385.013 nuts that fell onto wire screens rather than orchard soil in 2013 but not 2014.

Table 6. Kernel mold of three hazelnut breeding selections 379.050, 380.057, and 385.013 from nuts that had fallen onto orchard soil, weed cloth or suspended wire screens

\begin{tabular}{|c|c|c|c|c|c|}
\hline \multirow[b]{2}{*}{ Location of fallen nuts } & \multirow{2}{*}{$\frac{2012}{\operatorname{Mold}^{\mathrm{x}}(\% \text { kernels })^{\mathrm{y}}}$} & \multicolumn{2}{|c|}{2013} & \multicolumn{2}{|c|}{2014} \\
\hline & & Mold $^{\mathrm{x}}(\% \text { kernels })^{\mathrm{y}}$ & Moisture $^{\mathrm{z}}(\%)^{\mathrm{y}}$ & $\operatorname{Mold}^{\mathrm{x}}(\% \text { kernels })^{\mathrm{y}}$ & Moisture $^{\mathrm{z}}(\%)^{\mathrm{y}}$ \\
\hline \multicolumn{6}{|l|}{ Selection 379.050} \\
\hline Orchard soil & $27.0 \mathrm{a}$ & $15.3 \mathrm{a}$ & $21.3 \mathrm{a}$ & $32.8 \mathrm{a}$ & $31.6 \mathrm{a}$ \\
\hline Weed cloth & $25.0 \mathrm{a}$ & $10.9 \mathrm{~b}$ & $20.9 \mathrm{a}$ & $31.9 \mathrm{a}$ & $29.8 \mathrm{ab}$ \\
\hline Suspended wire screens & $24.8 \mathrm{a}$ & $10.4 \mathrm{~b}$ & $16.1 \mathrm{~b}$ & $27.4 \mathrm{~b}$ & $28.6 \mathrm{~b}$ \\
\hline \multicolumn{6}{|l|}{ Selection 380.057} \\
\hline Orchard soil & $4.3 \mathrm{a}$ & & & & \\
\hline Weed cloth & $2.5 \mathrm{a}$ & & & & \\
\hline Suspended wire screens & $6.3 \mathrm{a}$ & & & & \\
\hline \multicolumn{6}{|l|}{ Selection 385.013} \\
\hline Orchard soil & & $23.8 \mathrm{a}$ & $19.4 \mathrm{a}$ & $33.8 \mathrm{a}$ & $33.5 \mathrm{a}$ \\
\hline Weed cloth & & $17.4 \mathrm{~b}$ & $16.8 \mathrm{~b}$ & $30.3 \mathrm{~b}$ & $28.6 \mathrm{~b}$ \\
\hline Suspended wire screens & & $16.2 \mathrm{~b}$ & $13.9 \mathrm{c}$ & $30.1 \mathrm{~b}$ & $31.8 \mathrm{ab}$ \\
\hline
\end{tabular}

${ }^{\mathrm{x}}$ Unsterilized hazelnuts were cracked open and determined to have mold or not based on USDA inspection standards.

${ }^{y}$ Means followed by the same letter do not differ significantly based on Fisher's protected LSD $(P=0.05)$.

${ }^{\mathrm{z}}$ Nut moisture was accessed using the differential between weight of 25 nuts at harvest and weight after being dried at 70 to $80^{\circ} \mathrm{C}$ for 48 to $72 \mathrm{~h}$. 
The percentage of 385.013 kernels with mold was significantly lower on nuts that were allowed to fall onto weed cloth rather than onto orchard soil in 2013 and 2014 (Table 6). Nut moisture was also significantly lower for 385.013 nuts that fell onto weed cloth rather than orchard soil in 2013 and 2014. The percentage of 379.050 kernels with mold was significantly lower for nuts that fell onto weed cloth rather than orchard soil in 2013 but not 2012 or 2014 . Nut moisture was not significantly lower for 379.050 nuts that fell onto weed cloth rather than orchard soil in 2013 and 2014.

The percentage of Lewis kernels with mold was significantly lower on nuts that were allowed to fall onto weed cloth $(3.3 \%)$ or wire screens $(2.3 \%)$ rather than onto orchard soil $(6.5 \%)$ in 2014.

\section{Discussion}

Hazelnut kernel mold, as defined by the USDA, was associated with many different fungi in Oregon. Penicillium spp. were isolated most often from kernels with visible mold, but Aspergillus and Cladosporium spp., and D. rudis were also frequently isolated (Tables 1 and 2). These same fungi were also isolated from symptomless kernels (Table 3), suggesting mold may be due, in part, to latent infections prior to harvest. Many of these same genera have been found in kernels from hazelnuts grown in Turkey (Sezer and Dolar 2016; Şimşek et al. 2002) or Nebraska (Xu et al. 2011), from hazelnut markets in England (Kinderlerer and Phillips-Jones 1992) or Egypt (Abdel-Hafez and Saber 1993), and from other nut crops such as pecan (Huang and Hanlin 1975) and pistachio (Doster et al. 2002).

The one isolate of Penicillium used for further molecular identification matched $P$. chrysogenum, $P$. crustosum, and $P$. pseudocasei. The U.S. National Fungus Collections Fungal Database (Farr and Rossman 2017) considers $P$. pseudocasei as a synonym of $P$. crustosum. Both $P$. chrysogenum and $P$. crustosum have been isolated from hazelnuts obtained from markets in England and Egypt (Abdel-Hafez and Saber 1993; Kinderlerer and Phillips-Jones 1992), and have been associated with postharvest pome fruit rots (Farr and Rossman 2017; Rosenberger 2014).

The Cladosporium isolate is unlikely to be C. rhusicola as it has only been reported from South Africa while $C$. tenellum has been found from Corylus sp. in the PNW (Farr and Rossman 2017). Gnomoniopsis idaeicola has been reported from the PNW on canes of $R u$ bus sp. The rest of the fungi have been reported from many different regions worldwide and on many different hosts, but only Fusarium lateritium has been reported from Corylus avellana (Farr and Rossman 2017).

The yeast E. coryli (Halliwell and Miller 1962) or the fungus Ramularia sp. (Ebrahem et al. 1996) previously associated with kernel defects in Oregon were not found associated with kernel mold. Although this may only be due to the USDA definition of mold, we did not observe symptoms associated with the yeast disease known as kernel spot. Symptoms of tip mold, associated with Ramularia sp., were observed but did not meet the USDA definition of mold, and Ramularia sp. was almost never isolated from moldy kernels and only infrequently from symptomless kernels.

Many of the above fungi found on hazelnuts are favored by wet conditions. Moist chamber experiments showed that high humidity was enough to increase the incidence of mold on hazelnut. Nuts incubated on wet soil, autoclaved or not, also had elevated incidence of mold (Tables 4 and 5). Also, mold did not significantly increase even after nuts were incubated for 2 weeks in contact with dry soil. The hazelnut industry of Oregon has observed that early harvests (from dry soils) have low mold incidence, but after fall rains begin with nuts harvested from wet muddy soils, mold incidence is high (Shuster et al. 2017). The industry also noted that in 2016 lateseason nut deliveries to processors that included mud and orchard debris resulted in increased mold levels and grower monetary losses.

The difference in mold incidence between nuts incubated on wet, nonautoclaved and autoclaved soil is significant (Table 5). The results suggest that, on average, $68.5 \%$ of the mold may already be in the nuts as latent infections before the nuts fall to the ground. Soil moisture then provides the conditions necessary for mycelial growth on the kernel as nuts await harvest and processing. The tip mold pathogen,
M. punctiformis, and "other fungi" are reported to have been found in developing hazelnuts as early as mid-June (Doster et al. 2002). Latent infections at bloom with disease development at or near harvest is common among many other pathosystems such as gray mold of strawberry (Sutton 1998), mummy berry of blueberry (Scherm and Hildebrand 2017), and brown rot of stone fruit (Ogawa et al. 1995).

Preventing hazelnuts from coming in contact with wet soil using wire screens in the field resulted in significantly less mold development in two out of three years evaluated (Table 6). Nuts on screens still were subject to the same rainfall as nuts on the ground but had a greater chance to dry out between storms as measured by significantly lower nut moisture levels at harvest. Turkish hazelnut growers are advised to hand harvest or shake nuts from trees onto canvas sheets to prevent nut contact with the ground, which can result in a greater risk of mold and aflatoxin formation (Ozay et al. 2008).

Using weed cloth to prevent hazelnuts from coming in contact with soil was useful to lower mold development in breeding selection 385.013 and Lewis but was only significant one year out of three for breeding selection 379.050 (Table 6). Although nut moisture was lower for breeding selection 385.013 nuts on weed cloth, it was not significant for breeding selection 379.050 nuts. Although weed cloth is permeable, letting rainwater filter through to the soil, it may keep nuts wetter than the wire screens.

Oregon growers are not encouraged to adopt any of these specific tactics to prevent mold development. Elevated screens or sheets of any material would be impractical in large, mechanically harvested orchards. Hazelnuts are not suited for mechanical shaking of trees used typically for other crops such as almonds (Micke 1996) or cherries (Zhou et al. 2013). Hazelnuts mature and fall over several weeks rather than in a short time period, and trees have a very thin bark that could suffer trunk damage from shakers. Tactics that keep nuts dry such as early (multiple) harvesting during drier periods and/or protecting harvested bins from rain prior to processing are current recommendations in Oregon to minimize mold development (Pscheidt and Ocamb 2018).

Associations are only the first step in Koch's postulates, and future research has many challenges. Given the possible involvement of multiple fungi, kernel mold is likely a result of both spring and preharvest environmental factors. How, when, and where fungi are entering the nut and establishing latent infections prior to harvest is important to determine. The biology of the hazelnut makes this difficult to determine as fungi could gain entry into the nut anytime from bloom in January to harvest in October. Conditions other than soil wetness necessary for latent infections to transition into active mycelial growth, and thus be recognized as mold, need to be identified. Once these factors are known, Koch's postulates can be completed and determine if any of the fungi found on kernels are truly pathogenic.

\section{Acknowledgments}

We thank Jeff Newton for providing the 'Lewis' nuts for use in these experiments.

\section{Literature Cited}

Abdel-Hafez, A. I. I., and Saber, S. M. 1993. Mycoflora and mycotoxin of hazelnut (Corylus avellana L.) and walnut (Juglans regia L.) seeds in Egypt. Z. Mikrobiol. 148:137-147.

Anonymous. 2008. Filbert/Hazelnut Kernels and Filberts in the Shell. Inspection Instructions. USDA, Ag Marketing Service, Fruit and Veg Program, Fresh Products Branch.

Beyhan, N. 2000. The effect of different harvest times on some nut characteristics of hazelnut. J. Fac. Agric. OMU. 75:1-6.

Bobev, S. G., Angelov, L. T., Van Poucke, K., and Maes, M. 2018. First report of kernel spot caused by Eremothecium coryli on hazelnut in Bulgaria. Plant Dis. 102:243.

Doster, M. A., Johnson, K. B., Michailides, T. J., Stone, J. K., and Teviotdale, B. T 2002. Kernel decay. Pages 2-3 in: Compendium of Nut Crop Diseases in Temperate Zones. B. T. Teviotdale, T. J. Michailides, and J. W. Pscheidt, eds. American Phytopathological Society, St. Paul, MN.

Ebrahem, K., Richardson, D. G., Stone, J., and Tetley, R. 1996. Hazelnut kernel mold identification and timing of infestation. IV International Symposium on Hazelnut 445:483-484.

Farr, D. F., and Rossman, A. Y. Fungal Databases, U.S. National Fungus Collections, ARS, USDA. Retrieved September 15, 2017, from https://nt.arsgrin.gov/fungaldatabases/ 
Geiser, D. M., del Mar Jiménez-Gasco, M., Kang, S., Makalowska, I., Veeraraghavan, N., Ward, T. J., Zhang, N., Kuldau, G. A., and O'Donnell, K. 2004. FUSARIUM-ID v. 1.0: A DNA Sequence Database for Identifying Fusarium. Eur. J. Plant Pathol. 110:473-479.

Glass, N. L., and Donaldson, G. C. 1995. Development of primer sets designed for use with the PCR to amplify conserved genes from filamentous ascomycetes. Appl. Environ. Microbiol. 61:1323-1330.

Halliwell, R. S., and Miller, P. W. 1962. Kernel-spot of filberts found in Oregon. Plant Dis. Rep. 46:220.

Huang, L. H., and Hanlin, R. T. 1975. Fungi occurring in freshly harvested and inmarket pecans. Mycologia 67:689-700.

Kabak, B. 2016. Aflatoxins in hazelnuts and dried figs: Occurrence and exposure assessment. Food Chem. 211:8-16.

Kinderlerer, J. L., and Phillips-Jones, M. 1992. Mycology and spoilage of hazelnuts. Mod. Methods Food Mycol. 31:133-139.

McCluskey, R. L., Mehlenbacher, S. A., and Smith, D. C. 2011. 'Jefferson' Hazelnut (OSU 703.007). Oregon State University Extension Service. EM 9028 .

Mehlenbacher, S. A., Azarenko, A. N., Smith, D. C., and McCluskey, R. 2007. 'Santiam' hazelnut. HortScience 42:715-717.

Mehlenbacher, S. A., Smith, D. C., and Brenner, L. K. 1993. Variance components and heritability of nut and kernel defects in hazelnut. Plant Breed. 110:144-152.

Michailides, T. J., and Morgan, D. P. 1990. Etiology and transmission of stigmatomycosis disease of pistachio in California. (Abstr.). Phytopathology 80:973.

Micke, W. C. 1996. Almond production manual. U. Calif. Div. Agric. Natural Resour. Publ. \#3364.

Ogawa, J. M., Zehr, E. I., and Biggs, A. R. 1995. Brown rot. Pages 7-10 in: Compendium of Stone Fruit Diseases. J. M. Ogawa, E. I. Zehr, G. W.Bird, D. F. Ritchie, K.Uriu, and J. K. Uyemoto, eds. American Phytopathological Society, St. Paul, MN.

Ozay, G., Seyhan, F., Pembeci, C., Saklar, S., and Yilmaz, A. 2008. Factors influencing fungal and aflatoxin levels in Turkish hazelnuts (Corylus avellana L.) during growth, harvest, drying and storage: A 3-year study. Food Addit. Contam. 25:209-218.

Özilgen, M., and Özdemir, M. 2001. A review on grain and nut deterioration and design of the dryers for safe storage with special reference to Turkish hazelnuts. Crit. Rev. Food Sci. Nutr. 41:95-132.

Pscheidt, J. W., and Cluskey, S. A. 2001. Effect of plastic tents and fungicides on kernel mold of hazelnut. Fruit Ornam. Dis. Manage. Testing Program 2001:38 OSU Extension.

Pscheidt, J. W., and Cluskey, S. A. 2002. Effect of fungicides on kernel mold of hazelnut. Fruit Ornam. Dis. Manage. Testing Program 2002:43 OSU Extension.
Pscheidt, J. W., and Cluskey, S. A. 2003. Effect of fungicides on kernel mold of hazelnut. Fruit Ornam. Dis. Manage. Testing Program 2003:45-46 OSU Extension.

Pscheidt, J. W., and Cluskey, S. A. 2007. Hazelnut storage conditions relative to kernel mold development. Fruit Ornam. Dis. Manage. Testing Program 2007: 44 OSU Extension.

Pscheidt, J. W., Cluskey, S. A., and Stone, J. 2000. Plastic tents for reduction of kernel mold of hazelnut. Fruit Ornam. Dis. Manage. Testing Program 2000: 32 OSU Extension.

Pscheidt, J. W., and Ocamb, C. M., eds. 2018. Pacific Northwest Plant Disease Management Handbook. Oregon State University, Corvallis, OR.

Rehner, S. A., and Buckley, E. 2005. A Beauveria phylogeny inferred from nuclear ITS and EF1- $\alpha$ sequences: Evidence for cryptic diversification and links to Cordyceps teleomorphs. Mycologia 97:84-98.

Rosenberger, D. A. 2014. Blue mold. Pages 76-77 in: Compendium of Apple and Pear Diseases and Pests, 2nd ed. T. B. Sutton, H. S. Aldwinkle, A. M. Agnello, and J. F. Walgenbach, eds. American Phytopathological Society, St. Paul, MN.

Scherm, H., and Hildebrand, P. D. 2017. Mummy berry. Pages 30-32 in Compendium of Blueberry, Cranberry, and Lingonberry Diseases and Pests, 2nd ed. J. J. Polashock, F. L. Caruso, A. L. Averill, and A. C. Schilder, eds. American Phytopathological Society, St. Paul, MN.

Sezer, A., and Dolar, F. S. 2016. Hazelnut kernel defects and associated fungi in three provinces in Turkey. Pages 1312-1318 in: Proc. VII International Scientific Agriculture Symposium, Agrosym 2016.

Shuster, M., Rogers, T., Chapin, A., Kirk, L., and Horning, S. 2017. Receiving station panel. Proceedings of the Nut Growers Society of Oregon, Washington and British Columbia. 102:89-107.

Şimşek, O., Arici, M., and Demir, C. 2002. Mycoflora of hazelnut (Corylus avellana L.) and aflatoxin content in hazelnut kernels artificially infected with Aspergillus parasiticus. Nahrung 46:194-196.

Sutton, J. C. 1998. Botrytis fruit rot (gray mold) and blossom blight. Pages 28-31 in: Compendium of Strawberry Diseases, 2nd ed. J. L. Maas, ed. American Phytopathological Society, St. Paul, MN.

Tous, J., Romero, A., Sentis, X., Plana, J., Diaz, I., and Vargas, F. J. 2001 Influence of harvest period on hazelnut quality. Proceedings of the $\mathrm{V}$ International Congress on Hazelnut. Acta Hortic.: 567-574.

White, T. J., Bruns, T., Lee, S., and Taylor, J. 1990. Amplification and direct sequencing of fungal ribosomal RNA genes for phylogenetics. Pages 315-322 in: PCR Protocols: A Guide to Methods and Applications.

Xu, Y., Bianchini, A., and Hanna, M. A. 2011. Evaluation of mold and mycotoxin contaminations in hybrid hazelnuts grown in Nebraska. J. Food Process. Technol. 2:119.

Zhou, J., He, L., Zhang, Q., Du, X., Chen, D., and Karkee, M. 2013. Evaluation of the influence of shaking frequency and duration in mechanical harvesting of sweet cherry. Appl. Eng. Agric. 29:607-612. 